\title{
Copper and Aluminum smelters in Sadr city
}

\author{
Assistant Prof. Dr. Intesar Hassoon Redha Al-Salamy ${ }^{1}$
}

\begin{abstract}
The study displays facts and analysis of situations in Sadr city in terms of two major aspects, natural and human aspects and the influence of smelters on the community, recently the phenomenon of smelters were dramatically spread throughout Sadr city. high population density obliged the people to live in the form of large groups within small districts or areas of approximately (30 kilometers), while the rest of area belong to government, but after the regime had been changed in 2003 , and owing to the absence of security ,the people started to settle down illegally on public lands and government possessions. The process of people moving from former residences to these lands have caused confusion and disorder not only in housing side but in service and commercial and industrial aspects, however the high population help growing many crafts and Small or medium industries that don't need real capital or sophisticated machines or heavy equipment, so we will highlight in this study on three districts in Sadr city (Orfely -Kassrhe wa Atash- Tariq) where many aluminumcopper smelters are existed, we'll explore more and find out the suggestions that can improve the conditions of these areas.
\end{abstract}

Keywords: Copper, Aluminum ,Smelters, Industry, Economic growth, Sadr city.

\section{Introduction}

Problem of the study:

- What are the effects of smelters on Sadr city?

- Do the current factories rely fully on the products of smelters as raw materials in their production system?

- What type of substances that supposed to be smelted - and what kind of fuel used for smelters and How does the fuel affect the environment of the three neighborhoods?

\section{Hypothesis of the study}

In Sadr city there are various industrial activities which played actively including food - construction - mechanical - and mineral industries, but in this study we'll focus on the smelters that fall within the extent of mineral industry, and the residues of pollutant gases and solid or liquid waste generated from the smelters, which cause enormous environmental pollution, whose harmful effects on health were still being felt by many inhabitants.

\section{Methodology of the study}

The study adopted certain tools like: scientific descriptive manner and statistic data and also maps - tables- and field study in the concerned area,

\section{Limits of the study:}


The study dealt with an area of almost (30) square kilometers in period of time (20032017), Sadr City lies in northern- eastern part of Baghdad city, It is one of nine major sectors in Baghdad, it has rectangular territory shape extending from north-east to southwest of Baghdad, it flanked by (Qanat Al-Jaish line) to the west, (Al- Seddha Al-Turabia area) to the east, (Baghdad Al-Jidida city) to the south, (Sha'ab area) to the north, as it shown in map(1) (City hall of Sadr city, , 9-11-2017).

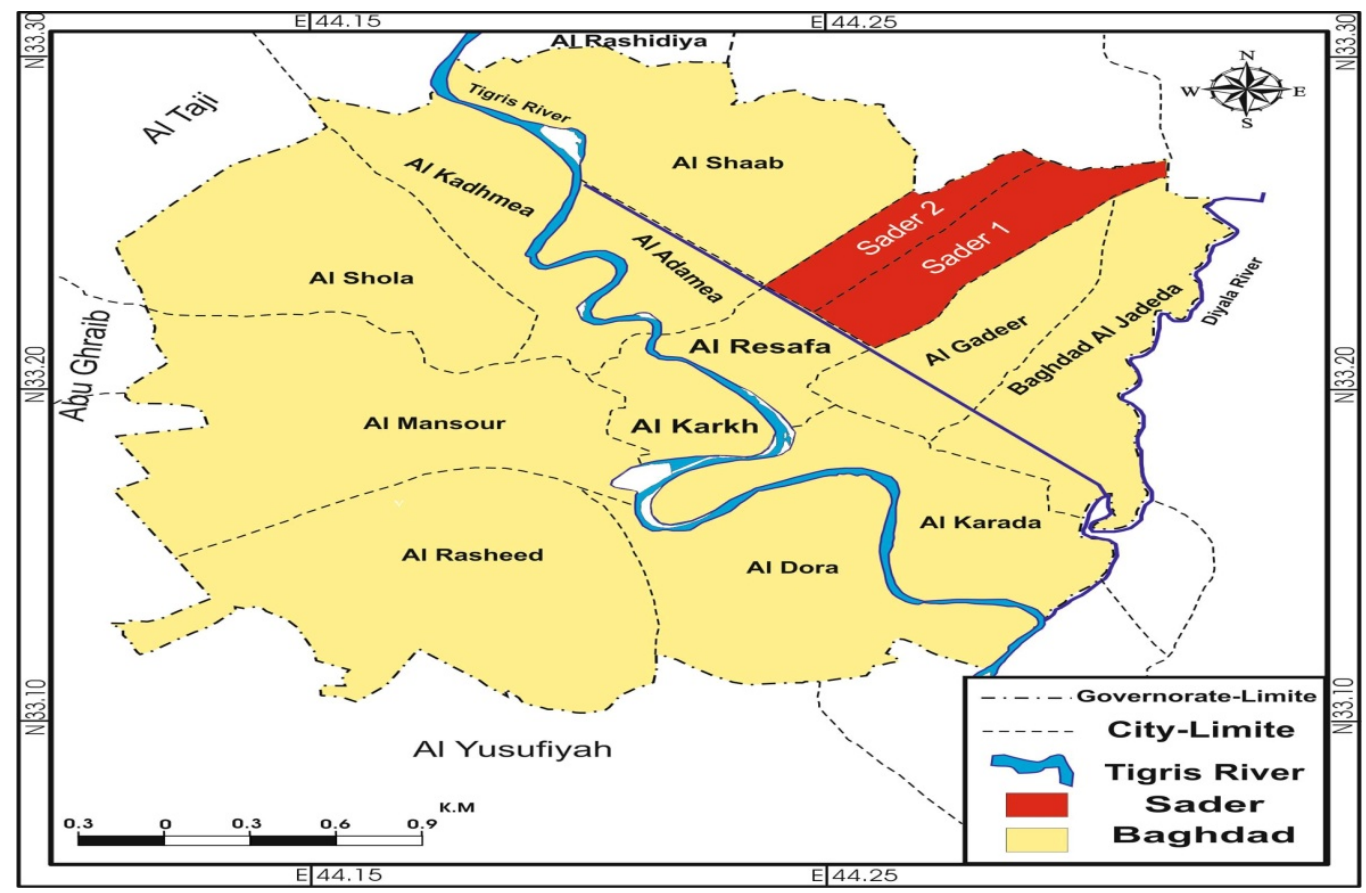

Map 1. Location of Al-Sader City in Baghdad Source : Municipality of Baghdad, Basic designing maps, Section of geographical data, administrative boundaries of Baghdad, 2016.

\section{First aspect:}

\subsection{Definition of smelters and its working mechanism:}

The smelter is a machine designed for smelting metals like (aluminum and copper), it is very much similar to a giant basin with legs pinned on the ground, the smelter is equipped with a lid on top of it, at the bottom there is hole to pour the smelted metals into the molds when the metals turn completely in the form of liquid, as it illustrated in the image (1). 


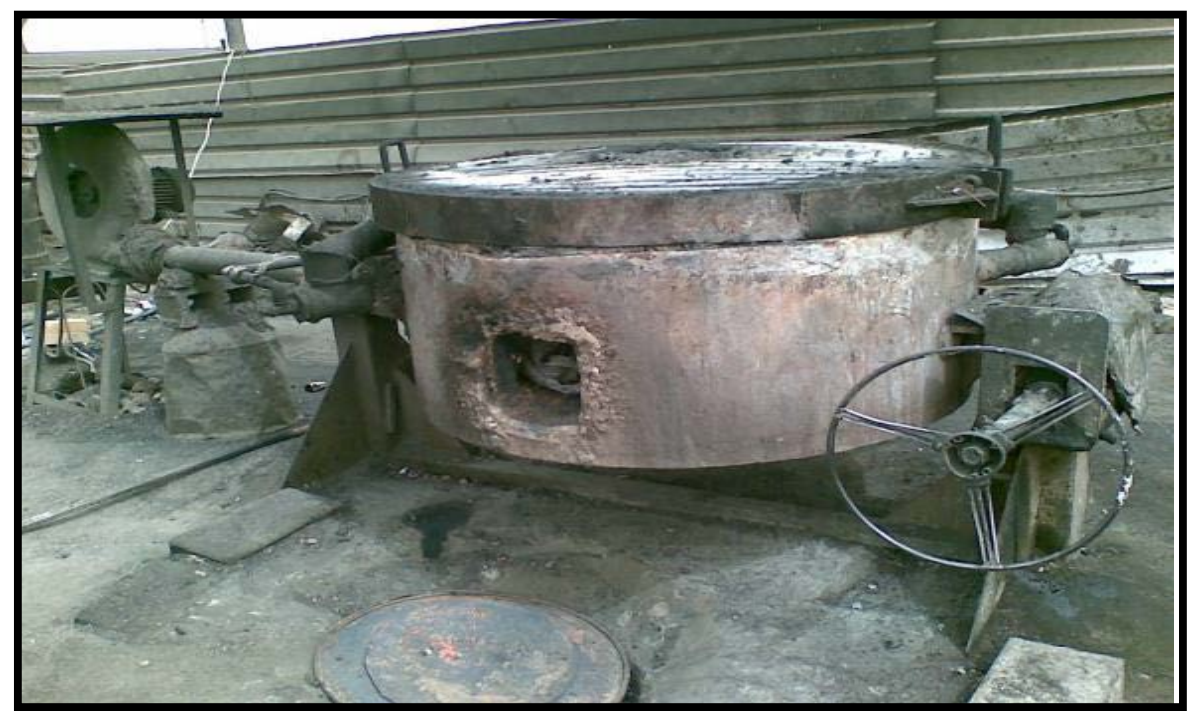

Figure 1 The Smelter described in the study

Source: Field study in the Area of study, 5-11-2017.

The operation get started when the blower (which is connected by tube on the side of the smelter, and it requires a substantial amount of electric power), puffs hot air stream as rotary movement way, meanwhile the smelter will flush fuel (black oil) by small tube installed inside of it, during that, the hot air is going to meet and mix with fuel that coming out of the tube, it's worth mention the ignition of fuel should be implemented manually, image (2) shows the shape of smelter.

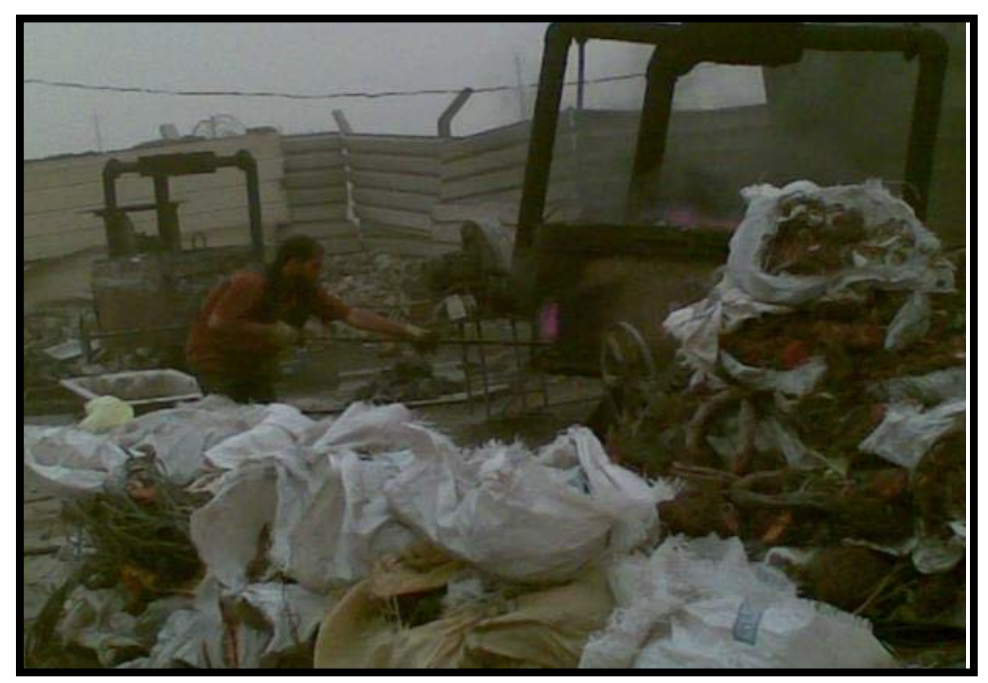

Fig. 2 Explain how to set the fire on inside the Smelter

Source: Field study in the Area of study, 511-2017.

After that, the worker stuffs metal scrap (ruined pieces contain aluminum and copper) in the smelter, it take to be completely smelted for a period of between half an hour to one hour, then it will be taken outside and poured into molds to cool it off, the alloys of copper or Aluminum will be extracted 
from the molds later, then the worker accumulate alloys up and send them to the factories to be manufactured for different uses (Field Study, 15-10-2017), image (3)

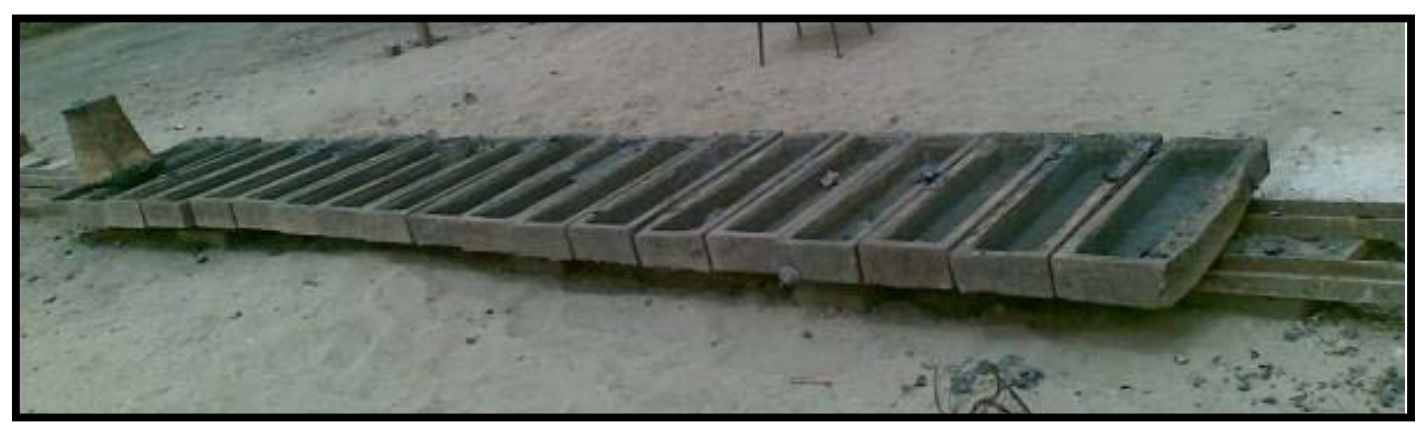

Fig. 3 shows the Smelted metal moldsSource: Field study in the Area of study, 5-11-2017.

Source: Field study in the Area of study, 5-11-2017.

\subsection{Spatial Distribution of Smelters in Sadr City A- Orfely District :}

Through the field study, it turns out, that there are 20 smelters in 2003-2007, (11) aluminum smelters and (9) copper smelters, each smelter has (4) foremen (skillful workers) and (8) unskilled workers, the daily production rate has reached to (20) molds of aluminum and (18) molds of copper per day, as it illustrated in table (1) and map (2), but because of the war and critical living conditions of the country starting from 2003, many of metal items and tools got damaged and the old devices and tools that stopped working or lost its efficiency should be disposed of them, and there is nothing to do about it just sending them to the "scrapyard" (it is place for gathering recyclable materials left over from consumption or unwanted materials, such as parts of vehicles, buildings, etc..), the junk at the end find its way to the street vendors who collect coppers and aluminum and sold them to special market called (Sooq Al-Wekfeh) in Orfely district, and finally the scrap is delivered to the smelters. the image (4) shows that, so Orfely area has been known for the abundance of smelted substances specially that had been used during 2003 war, most of copper and aluminum were extracted from remnants of munitions, so this period led to an increase in the number factories which dealt with processed (Copper or Aluminum Alloys) that were parts of house tools. (Field Study, 15-10-2017).

In 2008 and beyond, the smelters had been decreased in Orfely zone, only 3 of them remained, (1) copper smelter and (2) aluminum smelter, while the number of workers per smelter shrunk to 2 skillful workers (foremen) and 6 unskilled workers, as for the production, it also declined to (15) Aluminum molds and (10) copper molds per day, as it shown in table (1), map (3) . (Field Study, 15-10-2017). 


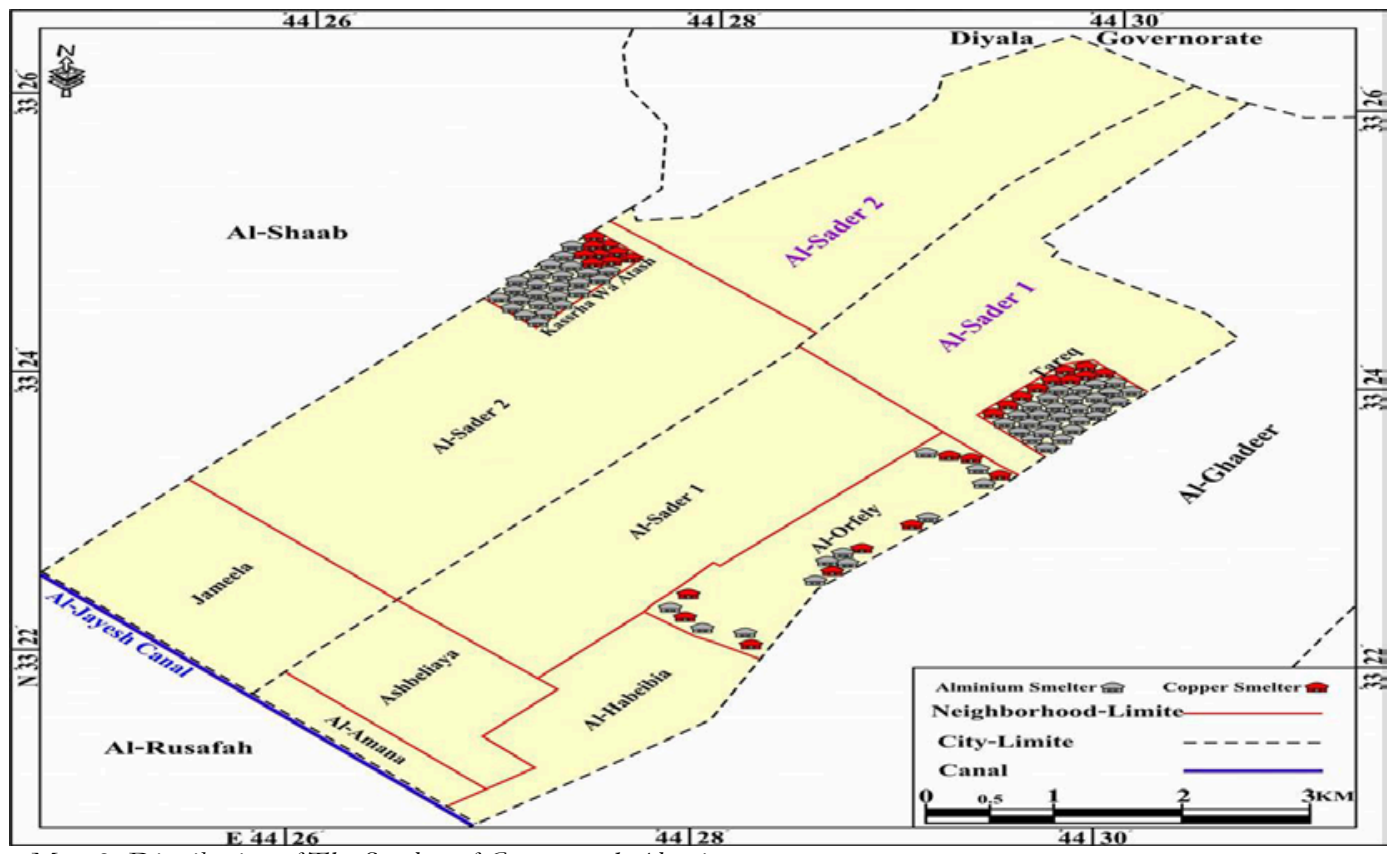

Map 2. Distribution of The Smelter of Copper and Aluminum

from 2003-2007 at the field study Source: Researcher's work based on field study.

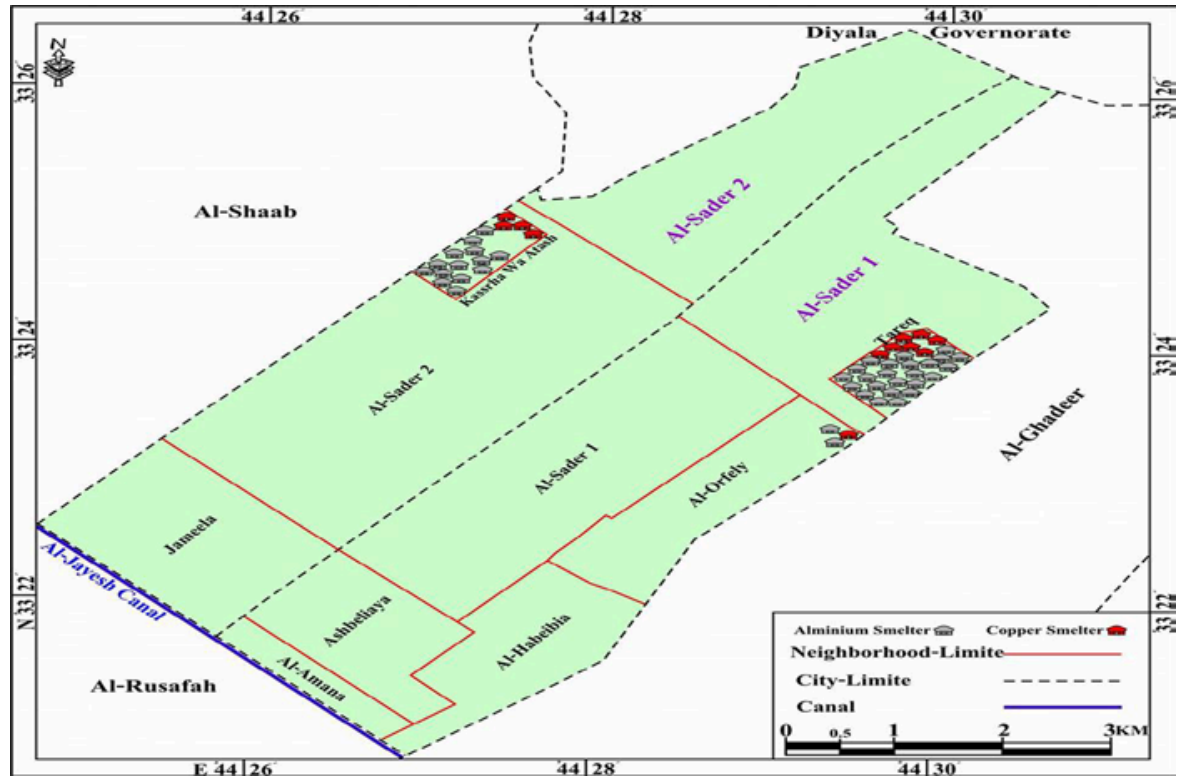

Map 3. Distribution of The Smelter of Copper and Aluminum

from 2008-2017 at the field study Source: Researcher's work based on field study. 


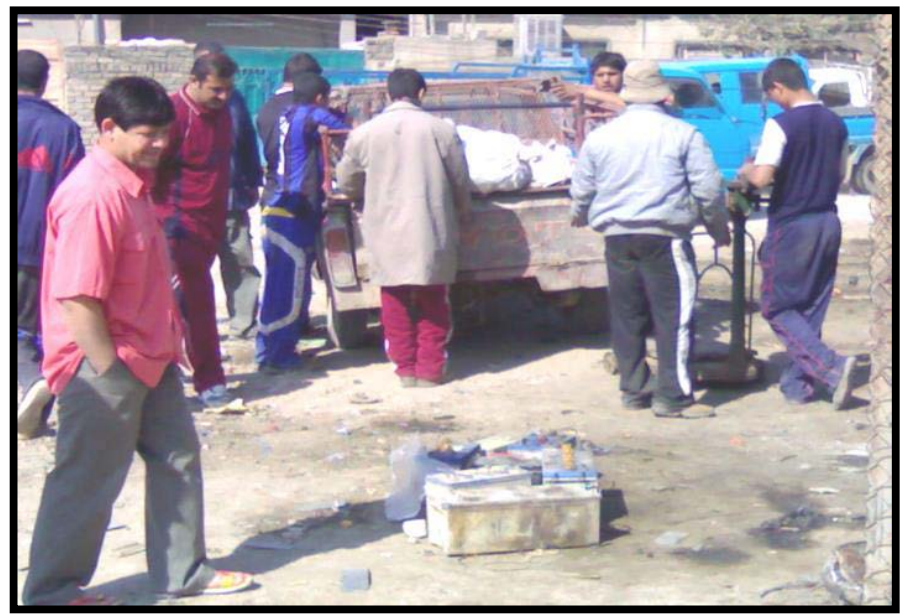

Figure 4. shows the street vendors sell the ruined metal (scrap) in market

(Sooq Al-Wekfeb)in Orfely district

Source: field study in the Area of study, 5-11-2017

Table 1. The quality and the amount of production and number of smelters and workers in study area (2003-2007) and (2008-2017)

\begin{tabular}{|c|c|c|c|c|c|c|c|c|c|c|c|c|c|c|}
\hline \multirow{3}{*}{$\begin{array}{l}\text { district } \\
\\
\text { Orfely }\end{array}$} & \multirow{3}{*}{\begin{tabular}{|l|}
$\begin{array}{l}\text { Type of } \\
\text { smelter }\end{array}$ \\
\\
A \\
C \\
\end{tabular}} & \multicolumn{4}{|c|}{ Number of smelters } & \multicolumn{5}{|c|}{ Number of workers } & \multicolumn{4}{|c|}{$\begin{array}{l}\text { The amount of production } \\
\text { for smelters }\end{array}$} \\
\hline & & \multicolumn{2}{|c|}{\begin{tabular}{|l|}
$(1) C$ \\
$A$ \\
$2003-$ \\
2007
\end{tabular}} & \multicolumn{2}{|c|}{$\begin{array}{l}\mathrm{C} \\
\mathrm{A} \\
2008- \\
2017\end{array}$} & \multicolumn{2}{|c|}{$\begin{array}{l}\text { Skillful - } \\
\text { unskilled } \\
2003-2007\end{array}$} & \multicolumn{2}{|c|}{$\begin{array}{l}\text { Skillful } \\
\text { unskilled } \\
2008 \\
2017\end{array}$} & & \multicolumn{2}{|c|}{\begin{tabular}{|lr|}
\multicolumn{3}{|l|}{ The production } \\
of molds \\
day & per \\
C & \\
A & \\
2003 & \\
2007 & - \\
\end{tabular}} & \multicolumn{2}{|c|}{\begin{tabular}{|l} 
The \\
production of \\
molds per day \\
C \\
A \\
2008 \\
2017
\end{tabular}} \\
\hline & & 9 & 11 & 1 & 2 & 4 & 8 & 2 & 6 & & 18 & 20 & 10 & 15 \\
\hline $\begin{array}{l}\text { Kassrah } \\
\text { wa } \\
\text { Attash }\end{array}$ & $\begin{array}{l}\text { A } \\
\text { C }\end{array}$ & 15 & 35 & 4 & 14 & 4 & 8 & 4 & 6 & & 22 & 35 & 12 & 22 \\
\hline Tariq & $\begin{array}{l}\mathrm{A} \\
\mathrm{C}\end{array}$ & 15 & 65 & 8 & 22 & 8 & 16 & 4 & 8 & & 15 & 30 & 8 & 15 \\
\hline otal & & 39 & 111 & 13 & 38 & 16 & 32 & 10 & 20 & & 55 & 85 & 30 & 52 \\
\hline
\end{tabular}

Source: The table made by personal effort of the researcher based on the data of field study in the study area 5-112017.

\section{B- Kassthe Wa Atash district:}

It is one of study areas that has some smelters, as it shown in table (1), the phenomenon of spreading smelters in 2003-2007, took its highest rate when the total amount of smelters was (50) smelters, (35) aluminum smelters and (15) copper smelters each smelter has (4) foremen (skillful workers) and (8) unskilled workers, the daily production rate had reached to (35) molds of aluminum and (22) molds of copper per day, as it illustrated in table (1) and map (2), note that the production rate is high due to most factories of (doors - windows - plates, etc.), which are concentrated in this area, rely

(1) $\mathrm{C}$ means copper, A means Aluminum 
mainly on the smelters production, like we said before the abundance of factories and industrial facilities had encouraged businessmen to establish smelters nearby. But since 2008 till 2017, the smelters were reduced because they are polluting the environment and many oversight committees were formed by municipality councils of Sadr city, according to the field study and what remains of smelters now, are (18), (4) copper smelters and (14) aluminum smelters, and the number of workers is (4) skillful workers and (6) unskilled workers for each smelter, and the production rate is (22) aluminum molds and (12) copper molds for one day, as it shown in map (3).

\section{C- Tareq district}

It is the third study area that took the interest of the searcher, the table (1) shows the distribution of smelters, in this area the smelters are evenly spread and adjacent to eastern area called "Seddhe", the study shows that the number of smelters between 20032007 was (80) smelters, (65) of them were aluminum smelters and the rest of them (15) are copper smelters, as it demonstrated in map (2), the number of working people in each smelter was (8) skillful workers and (16) unskilled workers, and the production rate for one day was about (30)molds of aluminum and (15) molds of copper, we can see the high production came from the availability of popular and local market that sell recyclable metals (scrap) besides multitude of street vendors scattering around this area (Tareq) and (Seddhe) area . in spite of the hazard that might follow this career, many people joined this risky job because of tough living conditions and the effects of poor education in the area .

In 2008 and beyond (till 2017) the number of smelters had fallen to (30) smelters spread just like before (spread out in a straight way) and adjacent to the (Seddhe Turabia) area , (8) of them were copper smelters and (22) were aluminum smelters and the working people is (4) skillful workers and (8) unskilled workers for each smelter, and the production rate was (15) aluminum molds and (8) copper molds for one day, as it shown in map (3).

\section{Second aspect: Economic effect of the smelters on the study area 5.1 Manpower}

Table (1) shows that smelters were good source of jobs opportunities, they provide livelihood for many families, since its appearance until 2017, no one can deny the interrelation between smelters and people, whenever the smelters goes up, the number of workers increases, The booming period of this industry was (2003-2007), the total number of workers for each smelter in the three areas (Orfely, Kassrhe wa Atash, Tareq) had reached respectively $(12,12,24)$ distributed between skilled and unskilled workers, as it indicated in table (1), but after 2008 and subsequent, many circumstances had been changed, the piles of junk and ruined metal pieces had diminished gradually, the number of workers per smelter went down in the three areas (Orfely, Kassrhe whe Atash, Tareq) which became respectively $(8,10,12)$ distributed between skilled and unskilled workers as it illustrated in table (1), and the reason for the decline in the number of smelters currently was the scarcity of copper or aluminum materials that most factories lean on and increasing direct importation and Non-imposition of taxes on foreign goods. (Field study, $5 / 11 / 2017$ ) 


\subsection{The amount of raw material (metal pieces that contain copper or aluminum)}

Table (1) shows, that the quantity of copper and aluminum (extracted from scrap) was at the highest rate during the period of study (2003-2007), because the metals (ruined - old metal pieces in which contain, most of its parts, copper or aluminum) were plentiful, as it mentioned before, and the production rate for one smelter in the three districts (Orfely, Kassrhe whe Atash, Tareq) was respectively (18-22-15) molds of copper while the aluminum the production rate was respectively (20-35-30) molds, but after 2008 and beyond till (2017), the production of the same districts had dropped significantly, it reached to (10-12-8) molds of copper, and the aluminum production for the same districts was respectively (15-22-15), as it shown in table (1), and the reason for the reduction of aluminum and copper production was the scarcity of copper or aluminum materials that were more available than the present, and increasing imported goods at cheap prices because it is not subject to customs fees. (Field study $, 5 / 11 / 2017)$

\subsection{Increasing the number of smelters}

Table (2) refers to the numbers of smelters of copper in the study area (three districts : Orfely, Kassrhe wa Atash, Tareq) during (2003-2008) was respectively $(1-3-1)$, and the smelters of aluminum was respectively $(2-4-3)$ for the same places and time. But between 2008 - 2017 the number of copper smelters in the same mentioned areas was respectively $(1-2-1)$ and the aluminum smelters was respectively $(5-8-7)$, This increase came as a result of the critical circumstances of our country, the abundance of sources substances led to the emergence of many factories in the study area .(Field study,5/11/2017).

Table 2. number of smelters between (2003 -2007) and (2008 - 2017)

\begin{tabular}{|l|l|l|l|}
\hline No & Districts & $\begin{array}{l}\text { Number of aluminum \& copper } \\
\text { smelters in the period } \\
\text { Copper - Aluminum } \\
(2003-2007)\end{array}$ & $\begin{array}{l}\text { number of aluminum \& copper } \\
\text { smelters in the period } \\
\text { Copper - Aluminum } \\
(2008-2017)\end{array}$ \\
\hline 1 & Orfely & $1-2$ & $1-5$ \\
\hline 2 & $\begin{array}{l}\text { Kassrhe } \\
\text { Atash }\end{array}$ & $3-4$ & $2-8$ \\
\hline 3 & Tareq & $1-3$ & $1-7$ \\
\hline Total & $4-9$ & $4-20$ \\
\hline
\end{tabular}

Source: The table is made by personal effort of the researcher based on the data of field study.

\subsection{The Capital:}

There is variation in the prices of scrap (from which copper \& aluminum are extracted), for instance, the purchase price of kilo of copper in the period (2003 -2007) was $(1,500)$ Dinars, while the aluminum, for the same period, was (500) Dinars, but in the period (2008-2017) the price of kilo of copper went up to $(2,500)$ Dinars and the aluminum was (750) Dinars, as it shown in table (3), if we compare between the first and second period (2003-2007 and 2008-2017), we will see the prices of first period are low but the prices getting raised during (2008-2017), the reason is already explained, in the first period the sources of junk (containing copper and aluminum) were widely available 
which leads to low stable prices, while (Unlike the situation in 2003-2007) in the second period the primary substances were notably decreased, as a result of this, the copper and aluminum prices rose significantly.

Table 3. The prices of junk to the periods (2003 -2007) and (2008- 2017)

\begin{tabular}{|l|l|l|l|}
\hline No & Districts & $\begin{array}{c}\text { The price of kilo } \\
\text { Copper - aluminum } \\
(2003-2007)\end{array}$ & $\begin{array}{l}\text { The price of kilo } \\
\text { Copper - aluminum } \\
(2008-2017)\end{array}$ \\
\hline 1 & Orfely & $1,500-500$ & $2,500-750$ \\
\hline 2 & Kassrhe wa Atash & $1,500-500$ & $2,500-750$ \\
\hline 3 & Tareq & $1,500-500$ & $2,500-750$ \\
\hline \multicolumn{2}{|l|}{ Total } & $1,500-500$ & $2,500-750$ \\
\hline
\end{tabular}

Source: The table is made by personal effort of the researcher based on the data of field study

\section{Third aspect}

\subsection{Residues of smelters and their negative environmental effects}

The concept of environmental pollution is the damages and bad effects originated from the sophistication of life and development of all aspects, this cause pollution, but to know more about the extent of environmental pollution, we should recognize first between "environment" and "pollution" concept.

Many studies and researches defined environment as the aggregate of surrounding things and conditions which constitute part of the world, that would the human affect and be affected by environment circumstances. (Abu Beker Seddiq Salem, Nebil Mahmood Abdulmonam, 1989,P.26-27)

As for the concept of pollution, it is identified as introduction of contaminants into the natural environment that cause adverse changes. So the action of pollution is the environmental contamination with man-made waste and it couldn't has the ability to cope with the waste via self- healing process.(Organization of Arab petroleum Exporting countries, 1982,P.29).

The pollution can be classified into several types, as indicated below: (Abu Beker Seddiq Salem, Nebil Mahmood Abdulmonam,1989,P.29).

1. Air pollution

2. Water pollution

3. Soil contamination

4. Food contamination

5. Radioactive contamination

6. Noise pollution

7. Visual pollution

What matters here in this study is the pollution caused by smelters in the study area, the pollution of smelters can be summarized into three types:

1. Air pollution

2. Noise pollution

3. Visual pollution. 


\subsection{First : Air pollution:}

The major cause of air pollution in the study area is the location of the city between two industrial areas: (Jameela and Kassrhe Wa Atash area), in addition to the some factories scattered around the city. The deployment of illegal industries like smelters played big role in polluting the air, because of gases released when the fuel "black oil" get burned and come out from smelters.

The gases of smelters are dangerous and bring considerable damages on the air and the health of people who lives in the area, image (5) shows the pollution.

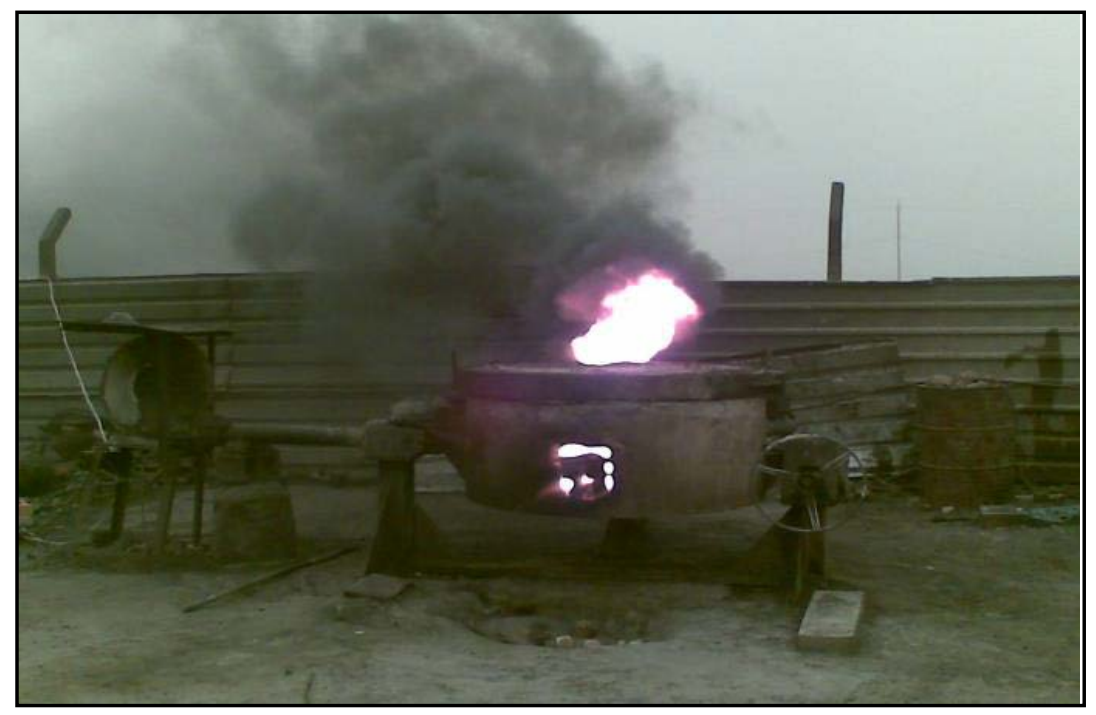

Figure 5. Airpollution due to operating of smelters Source: Field study, 5 - 11- 2017

\subsection{Second: The Visual Pollution}

The dust and gases and residues originated from smelters can cause " visual pollution" it can be created by throwing different kind of industrial trashes in the area, not to mention, the study area is characterized by high population and the people is already complaining about the spread of large amount of wastes which deepen the crisis. Therefore the smelters are responsible for releasing big amount of gases and pollutants (Field study, 5-11-2017).

\subsection{Third: Noise Pollution}

The loud and disturbing noises are kinds of pollution, the heavy machines and big equipment - industrial workshops and sounds of cars and alarms, all these elements create noise pollution, and what made matters worse is the phenomenon of smelters that launch big noises during the day even throughout night hours, so the smelters had an impact not only on the workers but people and surrounding areas, it causing serious harm to the human organs especially the ears and psychological state of people in the study area and other side effects like headache and anxiety or pressure (Field study, 511- 2017). 


\section{Suggestions}

1.Emphasize on the compulsory education to the kids and teenagers is one of the central tenets, the education bans the prevalence of exploitative child labour and other illegal acts like working in hazardous places like smelters industry.

2. Job creation is the best solution for many jobless university degree holders, this will help them to quit freelance businesses and start new life based on their graduation degrees.

3. Take advantage of the lands that had been overrun by violators, and use these lands in favour of common interest and adopt creative ideas like converting arid or undeveloped regions to green areas or rehabilitate lands for housing purposes.

4. Eliminate all the breaches and excesses occurred inside or on the outskirts of city, because if the lands are uncultivated or unused properly, the violators may exploit those lands in favor of their own interest and open up illegal smelters.

5. The municipality and city hall must remove all the unauthorized or unregistered smelters inside study area.

6. Formulate and activate legislations to protect the public lands from lawbreakers who exploit lands and properties that are not belong to them.

7. Operationalize the role of municipal supervision in the legislations pertaining to the constructions and buildings, to ensure that no one can transgress on the basic schemes of public building or government belongings.

\section{Conclusions}

1. There are several main factors have given rise to the phenomenon of smelters, among these reasons : Excessive population growth due to lack of birth control in the city and ongoing internal migration.

2. Many people who don't have educational achievement incline to the free business like establishing smelters or other similar industries, unfortunately there are many people had dropped out of schools owing to difficult living conditions.

3. Absence of the government agencies role which is supposed to put an end to this phenomenon.

4. Proliferation of consumables factories that rely basically on the items of copper and aluminum, thereby encouraging to surface great number of smelters nearby the factories, because they (smelters) are main purveyors for the primary substances (scrap).

5. The prevalence of this phenomenon in the study area had cause serious damages and environmental degradation like (air pollution - visual pollution -noise pollution etc..) which led to direct impact on the health and organs of human body.

\section{References}

Abu Beker Seddiq Salem, Nebil Mahmood Abdulmonam, the pollution between the problem and the solution, center of cultural books, Cairo, 1989, P.26-27.

Field study in Kassrhe whe Atash district for months (October - November), 2017.

Field study in Orfely district for months (October - November - December), 2017

Field study in Tareq district for months (October - November), 2017 
Municipality of Baghdad, basic designing maps, section of geographical information system of Baghdad, 2016.

Organization of Arab petroleum Exporting countries (OAPEC), symposium on environmental protection and ways of improving the environment from the Industrial Pollutants, 1982.. 